\title{
The Implementation of Lean Management in Accelerating Health Insurance Claim Process at Hospitals
}

\author{
Elisabeth Lia Friskasari*, Chriswardani Suryawati**, Henry Setyawan *** \\ *M Author Correspondence: lia.friskasari16@gmail.com \\ * Diponegoro University, Semarang City, Central Java Indonesia \\ ** Diponegoro University, Semarang City, Central Java Indonesia
}

*** Diponegoro University, Semarang City, Central Java Indonesia

\section{N D E X I N G}

Keywords:

Lean Management;

Health Insurance Claim;

Casemix;

\begin{abstract}
A B S T R AC T
Due to the changing payment system of healthcare services in the era of National Health Insurance from fee for service to be INACBGs (Indonesian Case Base Groups), health care financing system has changed from fee for service to INACBGs (Indonesian Case Base Groups) package system. In this case, hospitals especially the private ones, must have a stable financial capacity to be able to survive and operate. One of efforts to overcome this issue is to improve efficiency in all aspects and to make the claim submission on time. A continous improvement effort is needed to identify waste and improve the efficiency of a process, one of which is application of Lean Management. This study aimed to identify waste which can delays the process of claim submission. This study was conducted at a private hospital in Central Java. The research is a qualitative research with descriptive analytic methods. The result showed that the waste in the outpatient claim process was $52,4 \%$ and the waste in the inpatient claim process was $52,2 \%$ of all activities. The implementation of lean management for the process of health insurance claims was estimated to reduce the time cycle of outpatient claim process from 97.018 seconds to 181 seconds and the time cycle of inpatient claim process from 109.897 seconds to 406 seconds.
\end{abstract}

Kata kunci:

Manajemen Lean;

Klaim Asuransi

Kesehatan;

Casemix;
Dengan berubahnya sistem pembayaran pelayanan kesehatan di era Jaminan Kesehatan Nasional (JKN) dari fee for service menjadi sistem paket INACBGs (Indonesian Case Base Groups). Rumah Sakit terutama swasta harus memiliki kemampuan finansial yang stabil untuk mampu bertahan dan beroperasinal.Salah satu upayanya adalah dengan melakukan efisiensi di segala aspek dan mengupayakan agar klaim yang diajukan dapat dikirimkan tepat waktu. Diperlukan suatu upaya perbaikan berkelanjutan yang dapat mengidentifikasi waste, salah satunya adalah dengan penerapan Lean Management. Penelitian ini bertujuan untuk mengidentifikasi pemborosan (waste) pada proses pengajuan klaim yang menyebabkan pengiriman berkas klaim terlambat

Penelitian dilakukan di sebuah RS swasta di Jawa Tengah. Penelitian yang digunakan adalah jenis penelitian kualitatif dengan metode deskriptif analitik. Pengumpulan data dilakukan dengan observasi partisipatif dan wawancara mendalam (in-depth interview).Hasil penelitian menunjukkan bahwa aktivitas waste pada proses pengajuan klaim rawat jalan adalah sebesar 52,4\%, dan waste pada proses pengajuan klaim rawat inap adalah sebesar 52,2\% dari keseluruhan aktivitas, dengan jenis terbanyak adalah waste extra processing. Penerapan lean management pada proses pengajuan klaim asuransi kesehatan diperkirakan mampu menurunkan cycle time proses pengajuan klaim rawat jalan dari 97.018 detik menjadi 181 detik dan cycle time proses pengajuan klaim rawat inap dari 109.897 detik menjadi 406 detik.

2019 JMMR. All rights reserved

$\overline{\text { Article History: Received 2019-Aug-21; Revised 2019-Aug-23; Accepted 2019-Nov-20 }}$

\section{INTRODUCTION}

Health care facilities currently face major challenges with rising costs of patient care including medicines and medical devices. Hence, hospitals must eliminate any waste for efficient healthcare process. ${ }^{1}$ Waste in lean terminology can be interpreted as problems and disruptions that constantly arise and affect works or services for patients. ${ }^{2}$ In Japanese, waste is referred as muda, which are all actions carried out without adding / producing values. Taiichi Ohno (1988) devided waste in health services into seven types, and Linker (2006) further developed into eight types of waste, including Defect, Overproduction, Waiting, Non- 
utilized skills, Transportation, Inventory, Motion and extra processing (excessive / unnecessary process). ${ }^{3}$ One source even stated that employee behaviour is the ninth waste. ${ }^{4}$

A result of waste in health services is not only a waste of costs or material, but also, among others, extending patients' waiting time to get an emergency service ${ }^{5}$, the emergence of customers' and employees' dissatisfaction, extending Length of Stay (LOS) of patients' care, and the worse case is the occurrence of patients' safety incidents, such as infections (Hospital Acquired Infections), patients falling, the occurrence of patients' readmissions, medication errors, and even death. ${ }^{2,6}$ In the United States and Canada, the New England Journal of Medicine Study states that patients actually only receive $55 \%$ of the treatment that is really needed, which means that the rest is waste. ${ }^{7} \quad$ In terms of funding, Donald Berwick in 2012 conducted a study of waste in expenditure health costs in the United States. As a result, $40 \%$ of services are expressed as waste or not value-added care that is not unnecessary. ${ }^{8}$ In the same year, the Institute of Medicine estimated that one-third of health services in the United States were waste and the amount reached 765 billion dollars a year. ${ }^{2}$

Hospital $\mathrm{X}$ is a type-B public hospital in Central Java with a capacity of 345 beds managed by a religious foundation. Since 2014, Hospital X has partnered with Social Security Agency for Health in healthcare financing. Since then, the hospital has to adapt with a new health financing system. Before entering the era of National Health Insurance, hospital financing generally used the fee for service mechanism, meaning that all payments were in accordance to the amount of services provided. Entering the era of National Health Insurance, the government through BPJS Kesehatan has implemented a prospective financing system policy. Among the prospective payment models used in BPJS Kesehatan programs, the INA-CBGs (Indonesian Case Base Groups) package system is a cost system to pay for provided health services based on patients' disease groups. ${ }^{9}$ The amount of cost paid by BPJS Kesehatan is dependent on the accuracy of codification.

At the end of 2017, Hospital X formed a Casemix Team who were responsible for the coding process of BPJS Kesehatan claims. All BPJS Kesehatan services are expected to be coded and submitted on time. However, the claims have not properly been proceeded. Mostly, claims are filed later than the $10^{\text {th }}$, so it has potential to disrupt hospital's cash flow. Ideally, claims should be paid 15 days after the claim submission. ${ }^{10}$ The length of the casemix process / claim submission indicates that the process is inefficient and can be considered wasting. Here in after, collecting and sending claims claim will be referred as a casemix process.

The effort that must be carried out by hospitals to maintain its sustainability is by applying efficiency in all aspects without neglecting the quality of service and maximizing claims without fraud. ${ }^{11}$ To prevent continuous waste, waste must be prevented by certain systematicallydesigned methodologies. There are many methodologies regarding performance improvement. One of the most recent methods to overcome healthcare inefficiency is lean method. The application of lean management in health services has been proven to be able to eliminate waste, increase added value, and improve customer satisfaction. ${ }^{12}$ The lean movement that is currently occuring in several countries began to exist since the 1990s, but the elements and concepts had actually existed 100 years ago. ${ }^{13}$ The philosophy of lean or lean thinking was first pioneered by Toyota, which was initially only used in the industry or known as lean manufacturing and since 1990 it was quickly followed by practitioners of the health service industry, especially hospitals. ${ }^{14}$

Lean management is a continuous effort to minimize waste that will ultimately increase product's added-values to customers. ${ }^{1}$ In other words, lean management can increase the ratio of added values to waste. ${ }^{15}$ Lean management can be applied not only to service units that are directly related to patients, but can also be applied to administrative units, answering financial problems and improving services. ${ }^{2}$

\section{RESEARCH METHOD}

This research used a qualitative approach with an analytic descriptive method. Data were collected through observation and in-depth interviews. Observations were conducted in a participatory way, in which the researcher was directly involved to see the flow and waste in the casemix process. In-depth interviews were conducted to explore the causes of waste and obstacles.

The respondents in this study were representatives of Casemix Team members while the object of this study was the claim documents/files. The number of document samples was calculated by the Lemeshow formula. As a result, there were 100 claim files that were proportionally divided into 80 outpatient files and 20 inpatient files.

This study was conducted in three stages. In the first stage, the casemix team were observed byrecording 100 casemix files from their first entry until final documents. The record sinclude time and constraints / waste that 
occurred during the process. From the observations, the casemix process flowchart and current value stream mapping were designed. At the same time, the respondents were interviewed about workflows, work processes and constraints. In the second stage, Value Assessment was carried out using guidelines and analysis so that addedvalue activities, non-Value-Added(waste) activities, and non-added-value but necessary activities could be distinguished. In the last stage, the causes of waste were identified. At the same time, an improvement proposal was designed. Then, a future state value stream mapping could be prepared.

\section{RESULT AND DISCUSSION}

The informants in this study consisted of 10 main respondents and 2 triangulation respondents. All respondents were selected according to inclusion criteria and research needs. The main respondents were Casemix team as the implementers and the Finance Director. Besides, the triangulation respondents were the Casemix team leader and the Managing Director.

From the first observation, the following is the obtained results :

\section{Flowchart of casemix process}

\section{Casemix process of outpatient files}

It consists of file reception stage, coding and verification stage, scanning stage, and financial input stage.

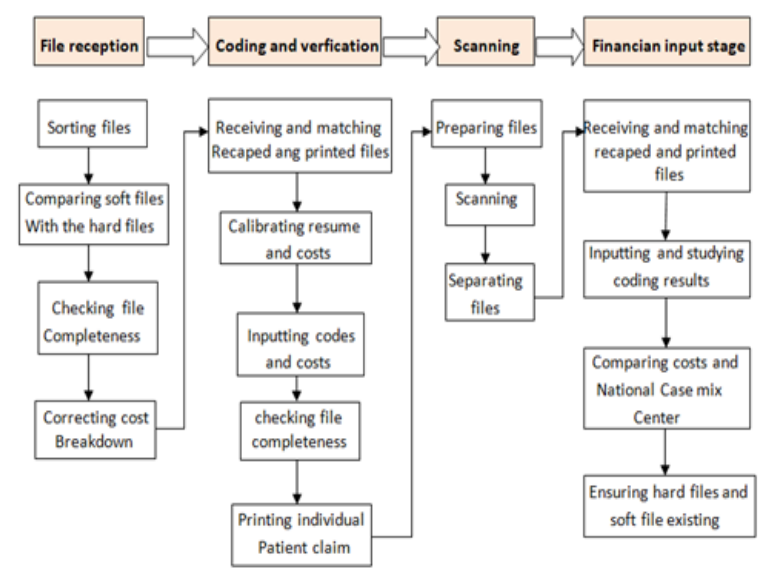

Figure 1. Flowchart of outpatient casemix file process

\section{Casemix process of inpatient files}

It consiss of file reception stage, coding and verification stage, scanning stage, payment stage and financial input stage

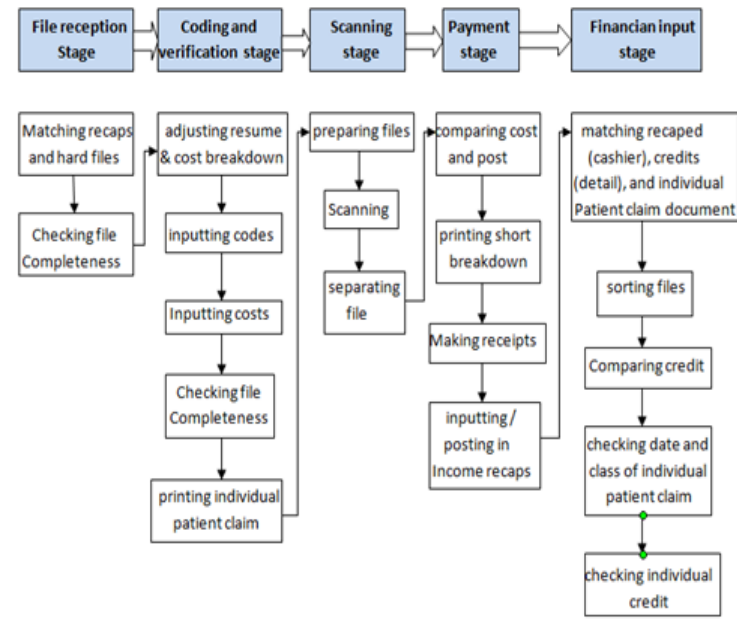

Figure 2. Flowchart of inpatient casemix file process

\section{Current State Value Stream Mapping \\ Current State Value Stream Mapping of Outpatient Files}
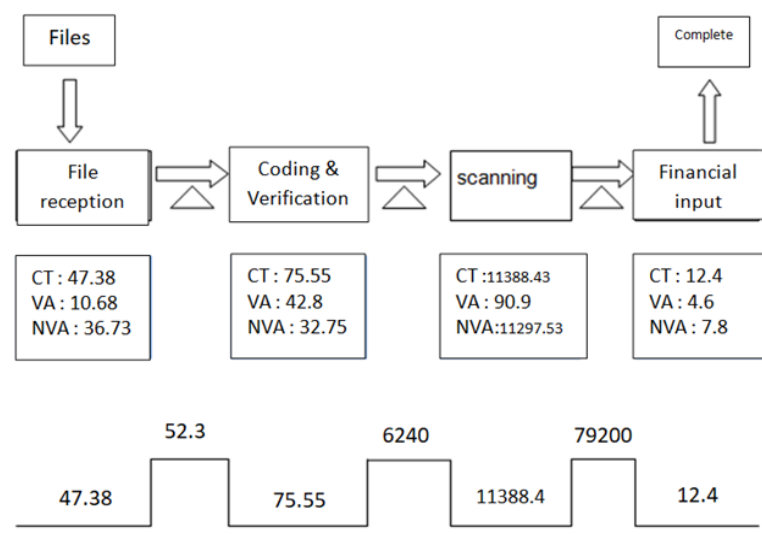

Figure 3. Current State Value Stream Mapping of Outpatient Files (CT: Cycle Time; VA: Value added activities; NVA ; Non Value Added activities)

The total time needed for one file to proceed to be filed was $97.018,97$ seconds or approximately 27 hours. It occurred because the processes could not be done continuously. There was a stage where the file was waiting for the next process. Waiting Time (WT) from the file reception stage to the verification coding stage was an average of 52.3 seconds. It happened because the finance staffs and coding staffs worked in different rooms, so they spent more time to walk into the coding room / casemix staff. From coding and verification stage to scanning stage, the waiting time was 6240 seconds because the files were not immediately scanned. The scanning stage was only done when the files were compiled into one bundle. At the 
scanning stage, the prepared files were also not immediately scanned, so it caused waiting time too.

After scanning, the files did not directly undergo financial input, but they waited until all outpatient files were scanned. In most cases, financial inputs could only be done in the following day. As a result, it needs 79.200 seconds to proceed.

\section{Current State Value Stream Mapping of Inpatient Files}
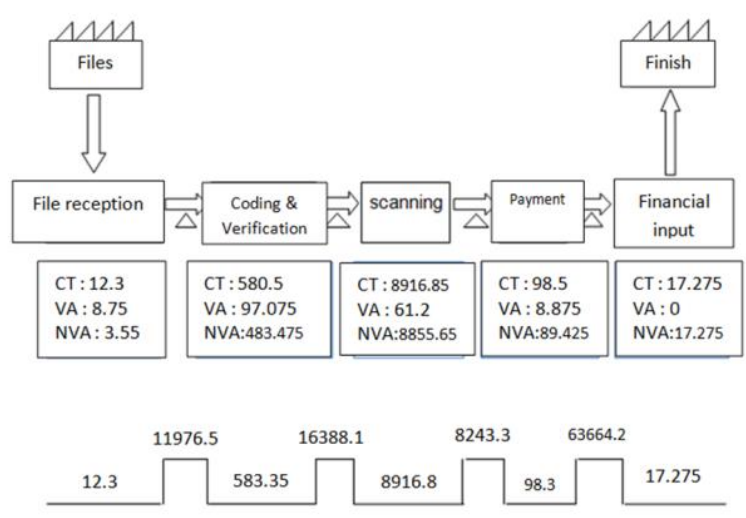

Figure 4. Current State Value Stream Mapping of Inpatient Files (CT: Cycle Time; VA: Value added activities; NVA ; Non Value Added activities)

Similar to the outpatient casemix process, the process from one stage to another rcould not be done continuously.
Waiting Time (WT) spent from the file reception to the verification and coding stage was an average of 11.976,5 seconds due to codification delay by casemix doctors. The incomplete inpatients' claim files must be done first according to the date of return. From coding and verification stage to scanning stage, there was also a waiting time / WT of $16.388,1$ seconds because the scanning staffs early scanned the file.

Files which were not directly scanned caused pause / waiting time before being scanned. After scanning, the files were not immediately handed over to the inpatient cashier staffs for receipts printing. The files were printed within 1 day with waiting time of $8.243,3$ seconds. In the last stage, the finance staffs inputted the files, but they could not accomplish it quickly. While the cashier had just finished the process in the afternoon, the finance staffs did not stand by. The required waiting time to hand out the files from cashier to the financial staffs was $63.664,2$ seconds. The total time for one file submission was $109.897,3$ seconds or about 30 hours.

Value-Added Assessment

Value-Added Assessment of Outpatient Casemix Process

Table 1. Value-Added Assesment of Outpatient Casemix File Process

\begin{tabular}{|c|c|c|c|c|c|c|}
\hline No & Stage & Activities & $\mathbf{V A}$ & NNVA & Waste & Detail \\
\hline \multirow[t]{4}{*}{1.} & File reception & Sorting File & Yes & & & \\
\hline & & Matching files & & Yes & & \\
\hline & & Correcting details & & & Yes & Defect \\
\hline & & Moving & & & Yes & Transportation, Motion \\
\hline \multirow{5}{*}{2.} & verification & & & & & \\
\hline & & Calibrating resumes and costs & & Yes & & \\
\hline & & Inputting codes & Yes & & & \\
\hline & & Inputting costs & & Yes & & \\
\hline & & Checking completeness & & & Yes & Extra processing \\
\hline \multirow[t]{5}{*}{3.} & Scanning & Preparing files & & & Yes & Extra processing \\
\hline & & Waiting & & & Yes & Waiting \\
\hline & & Scanning & Yes & & & \\
\hline & & Separating files & Yes & & & \\
\hline & & Waiting and moving & & & Yes & $\begin{array}{l}\text { Waiting, motion, } \\
\text { transportation }\end{array}$ \\
\hline \multirow[t]{3}{*}{4.} & Financial Input & Matching file & & & Yes & Extra processing \\
\hline & & Inputting coding results & & & Yes & Extra processing \\
\hline & & Matching costs and NCC & & & Yes & Extra processing \\
\hline
\end{tabular}


Value-Added Assessment shows that Value-Added activities, non-value-added but necessary activities, and waste are in the ratio of $33.3 \%: 14.3 \%: 52.4 \%$. It indicates that the on-going outpatient casemix process is not in the lean condition. The wastes found areas follows:

\section{Waste of Defects}

In the file reception, there could be an incongruity between the doctor's résumé and cost breakdown. If it is not corrected, the BPJS Kesehatan will reject the claim and eventually cause a payment delay. Such correction needs lots of time and can be considered as a waste of defect. It requires time to correct something that is not done from the beginning. ${ }^{2}$

\section{Waste of Transportation and Waste of Motion}

Between file reception and coding stage and between scanning and financial input stage, there was a lapse of time while staffs moved from the financial room to coding room and vice versa because of seperate rooms. Such lapse of time is called waste of transportation, which refers to the excessive movement of products. ${ }^{2}$ Waste of transportation causes waste of waiting and waste of motion due to poor layout. $^{16}$

\section{Waste of Extra Processing}

In the outpatient casemix process, the financial staffs and coding staffs checked file completeness. This process is considered waste of extra processing. ${ }^{2}$ One of the causes of waste of extraprocessing is ineffective procedures and policies. $^{3}$

\section{Waste of Waiting}

This waste occurrs in every stage. Once a file was completed, it was stacked unlessevery other file or some other files were complete. In fact, some files were only done in the next morning due to different division/office room.

\section{Value-AddedAssessment of Inpatient Casemix Process}

Table 2. Value-Added Assessment of Inpatient Casemix File Proces

\begin{tabular}{|c|c|c|c|c|c|c|}
\hline No & Stage & Activities & VA & NNVA & Waste & Detail \\
\hline \multirow[t]{4}{*}{1.} & File reception & Matching recap and printed & & Yes & & \\
\hline & & files & & & & \\
\hline & & Checking file completeness & Yes & & & \\
\hline & & Waiting & & & Yes & Waiting \\
\hline \multirow[t]{19}{*}{2.} & Coding and verification & Calibrating resume and costs & & Yes & & \\
\hline & & Inputting codes & Yes & & & \\
\hline & & Calculating and inputting & & & Yes & Extra processing \\
\hline & & costs & & & & \\
\hline & & Checking files completeness & & & Yes & Extra processing \\
\hline & & Printing individual Patient & Yes & & & \\
\hline & & Claim Document & & & & \\
\hline & & Waiting & & & Yes & Waiting \\
\hline & Scanning & Preparing files & & & Yes & Extra processing \\
\hline & & Waiting & & & Yes & Waiting \\
\hline & & Scanning & Yes & & & \\
\hline & & Separating files & Yes & & & \\
\hline & & Waiting and moving & & & Yes & $\begin{array}{l}\text { Waiting, motion and } \\
\text { transportation }\end{array}$ \\
\hline & Payment & Matching costs with posts & & & Yes & Extra processing \\
\hline & & & & & & anddefect \\
\hline & & Printing short details & Yes & & & \\
\hline & & Writing receipts & & Yes & & \\
\hline & & Recaping income & & Yes & & \\
\hline & & Waiting and moving & & & & $\begin{array}{l}\text { Waiting, motion and } \\
\text { transportation }\end{array}$ \\
\hline
\end{tabular}




\begin{tabular}{|c|c|c|c|c|c|c|}
\hline No & Stage & Activities & VA & NNVA & Waste & Detail \\
\hline \multirow[t]{13}{*}{5.} & Financial input & Matching income & & & Yes & Extra processing and \\
\hline & & recapitulation, credits and & & & & defect \\
\hline & & costs for individual patient & & & & \\
\hline & & claim document & & & & \\
\hline & & Sorting files & & Yes & & \\
\hline & & Matching income and credits & & & Yes & Extra processing and \\
\hline & & with cost of individual patient & & & & defect \\
\hline & & claim document & & & & \\
\hline & & Checking dates and classes of & & & Yes & Extra processing and \\
\hline & & individual patient claim & & & & defect \\
\hline & & document & & & & \\
\hline & & Checking individual credit & & & Yes & Extra processing and \\
\hline & & & & & & defect \\
\hline & TOTAL & & $26,1 \%$ & $21,7 \%$ & $52,2 \%$ & \\
\hline
\end{tabular}

The results of Value-Added Assessment show the composition of Value-Added activities, non-value-added activities, and waste with the ratio of $26.1 \%: 21.7 \%$ : $52.2 \%$. It points out that ongoing inpatient casemix process is not in the lean condition. A company can be categorized as lean if thewaste ratio with the total activity reaches a minimum of $30 \%{ }^{2}$ The waste found was as following:

\section{Waste of Extra Processing}

In the coding and verification stage, cost was recalculated before being inputted to the claim program. However, the program designed by IT division for calculating the cost does not run well and causes waste of extra processing.

Like outpatient casemix file process, the doublechecks on the completeness of claim documents by the administration staffs and casemix doctors also indicatewaste of extra processing. ${ }^{2}$

Waste of extra processing could also be found in the financial input stage. The staff had to input and match the financial data with income recapitulation and financial report although the data weredrawn from the same source.

\section{Waste of Defect}

Waste of defect occurs when incomplete claim files are found during checking stage. For instance, a medical resume is missing, operation report is not attached, chronological letter is incomplete, etc. It was found that mostly medical resumes are incomplete, so the staffs borrowed medical records or assign doctors at the outpatient unit or inpatient unit to fill the medical resumes. Since this activity takes long, it is considered as a waste of defect.

\section{Waste of Waiting}

Similarly to the outpatient casemix process, the inpatient casemix process has a lapse of time every time the stage changes due to an incomplete files. Incomplete files will not be immediately reported to the next stage before all or some other files were completed.

\section{Waste of Transportation and Motion}

This waste was also found in the inpatient casemix process since the inpatient administrative staffs or cashiers, financial staffs, and coding staffs have different rooms.

From the whole process, both outpatient and inpatient casemix processes, the most widely found waste was waste of extraprocessing $(60 \%)$. In previous studies about lean hospitals in service units, the most waste encountered was waste of waiting. In a study by Nancy in 2017 entitled Lean Hospital Approach for Sustainable Improvement in the Service Process of Pharmacy Installation at Betesda Hospital Yogyakarta, the first rank in pharmaceutical satellite services was waste of waiting, followed by waste of motion and transportation. ${ }^{17}$ In line with the study, a study by Chan HY in 2014 at the Emergency Unit stated that the most waste which was time consuming was waste of waiting. ${ }^{18}$

\section{Layout}

The large amount of waste of transportation and motion occurs because of poor layout. ${ }^{16}$ The following is a spaghetti diagram that illustrates the movement of casemix files and staffs from one room to another. The red lines illustrate the process of outpatient files while the blue lines illustrate the process of inpatient files. 


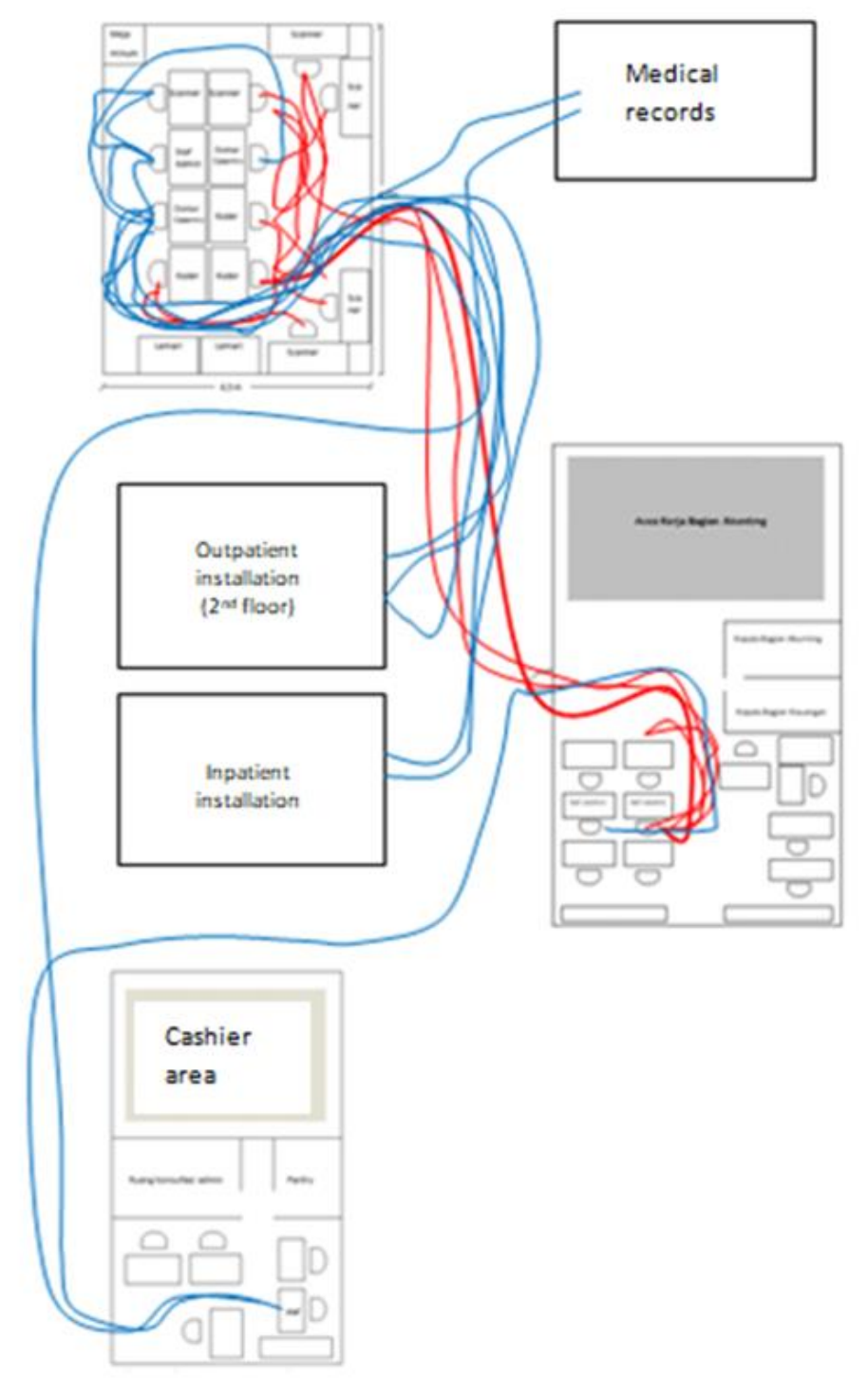

Figure 5. Sphaghetti diagram of Inpatien and Outpatient Casemix File Process

\section{Cause of Waste Identification}

Identification of waste cause is illustrated in the following fishbone diagram:

\section{Cause of Waste of Defect}

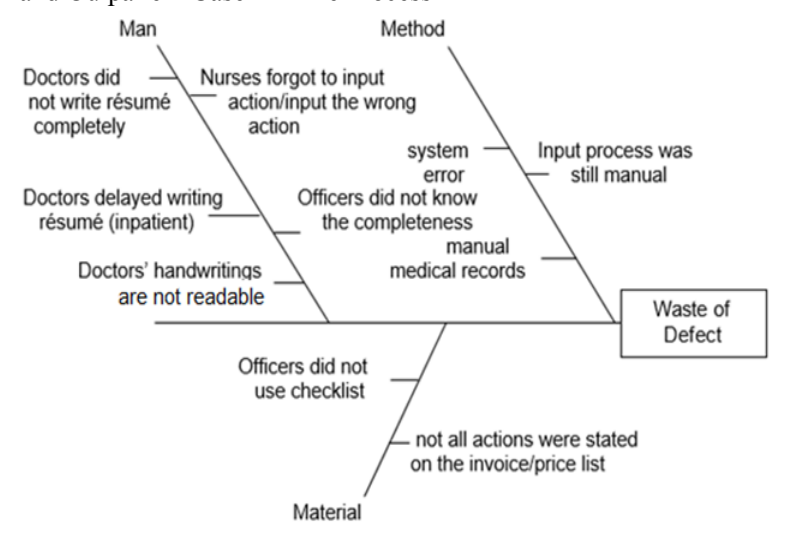

Figure 6. Cause of waste of defect fishbone diagram 
Waste of defect in the casemix process, among others: making corrections to the details of patients' costs / billing, making corrections / completing doctor's resume, completing the claim file, and making corrections to the financial statements.

The causes of waste of defect in terms of Man include doctors not writing a complete resume, doctors not immediately completing resumes, doctor's writings are not readable, officers / nurses do wrong input actions / facilities, and officers do not understand the completeness of the claim file. These things cause defects which require considerable time to be corrected. ${ }^{2}$

The incompleteness of this medical resume is in accordance with a study conducted by Dewi Apriyantini at Fatmawati Hospital Jakarta in 2016. The result is incomplete diagnostic filling (secondary) of $39 \%$ due to the Standard Operating Procedure that has not been run optimally, the unavailability of direct reward and punishment and the unavailability of a continuous socialization system. ${ }^{19}$

A study conducted by Irmawaty Indar (2013) about the completeness of medical records shows that the factors that influence a doctor in writing the right medical record are employment status (civil servants and non-civil servants), knowledge, and length of service. ${ }^{20}$

While the cause of waste of defect in terms of method / process is the occurrence of an error system, manual financial input processes and medical records are still manual (not electronic). System error is difficult to avoid, but it can still be fixed. As a result of this system error, the data obtained at one time are not the same, so it takes time to check and revise the data. The financial input process at the cashier that is still manual can also trigger input errors due to misreading rates. In the future process, it will cause waste of defect which need improvements. The last thing is if the medical record is still manual, the process of requesting the completeness of the file to the doctor will take a long time in searching the medical record file, waiting for the doctor to fill out (can be more than one day).

In terms of material / infrastructure, the cause of waste of defect is that officers do not use the existing checklist, and not all actions are available in the billing system / hospital action rates list. Patients who do not use a checklist will potentially have an incomplete claim file when the claim process is completed. Casemix administration officers must look for the completeness of the claim file first, which requires a long time, whether it is a resume, action report, supporting file, etc. In some instances, there are actions taken by doctors that are not on the billing list, so it is not right if nurses input the costs. Consequently, it causes waste of defect because it requires time to make corrections.

\section{Cause of Waste of Extra Processing}

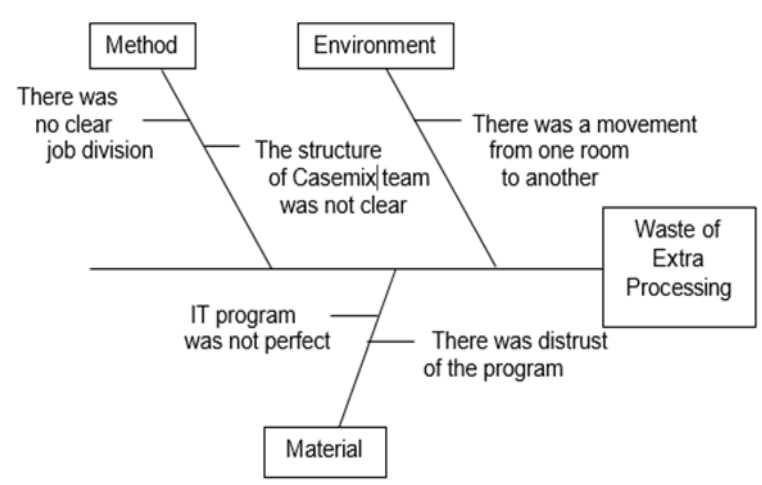

Picture 7. Cause of waste of extra processing fishbone diagram

Waste of extra processing refers to doing something extra / higher than what is needed or doing unnecessary work. $^{2}$ No clear job distribution also contributes to the occurrence of extra processing waste, in which each staff can do the same thing at different stages. File completeness checking in the outpatient casemix process is carried out at the file receiving and coding stage. Likewise, file completeness checking in the inpatient casemix process is done twice, including the file acceptance stage and the coding and verification stage. Unclear job distribution also occurs at the financial stage of inpatient input, and the cashier stage, in which the activity of checking rates with the posting should not need to be done in order to make receipts. These activities should have been carried out at the financial input stage without the file being sent to the cashier / inpatient administration first. Lack of communication can also be a cause of this waste of extra processing. If traced further, the lack of clarity in the structure of the Casemix Team also contributed to this waste. Although it is formed in a team through the Decree of the Director, the Casemix Team has members in which each member has their respective structural heads. Job or daily work is not only governed by the chairman of the Casemix Team, but also is governed by each head.

Another cause of waste of extra processing is the transfer of room from one room to another in the casemix process. The financial staff has a separate room, the coders and scanners have a separate room, and the cashier / inpatient administration has a separate room. Thus, to transfer the file from one room to another to the next stage, 
file handover is needed, which means the officer must match whether the file is received according to what was supposed to avoid file loss. In fact, it is not necessary to match the physical recap and file at the coding and verification stage, and when returning to the financial room again.

The incomplete cost split program that has been created by the IT Hospital also causes extra processing waste, in which the coders must recalculate the grouping of each cost. The final costs often do not match with the existing programs, which means having to do a recalculation to match them. Meanwhile, staff distrust of the program can also cause waste of extra processing. The financial officer must double-check the results of INA CBG rates in both the physical file, the NCC download / claim results, and in the financial reports.

Meanwhile, waste of extra processing from the activity of preparing files before scanning is done, because the officers want an easier job according to them but longer in time calculation.

\section{Cause of Waste of Waiting}

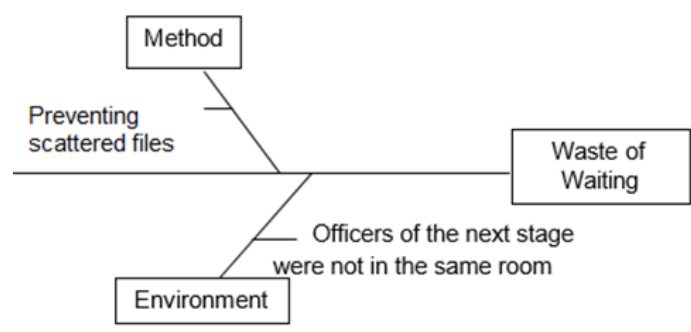

Picture 8. Cause of Waste of Waiting Fishone Diagram

Waste of waiting can be defined as time wasted when no value-added activities occur. ${ }^{2}$ The cause of waste of waiting is that the processed file cannot be transfered directly from one stage to the next, but is stacked or waiting to be completed until the whole file is ready. This is to avoid the risk of files being scattered by the officers in the later stages as they are not in the same room.

\section{Cause of Waste of Transportation}

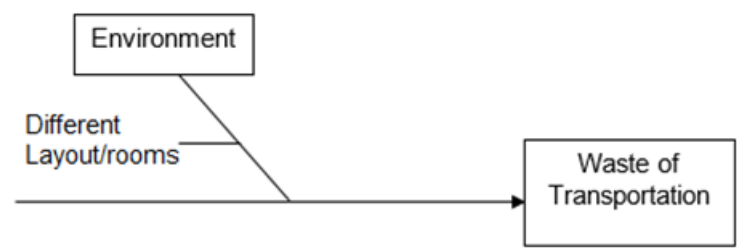

Picture 9. Cause of Waste of Transportation Fishbone Diagram
The only cause in Waste of Transportation is because the workspaces are different from one officer to another or between one stage to another. Waste of transportation refers to excessive product movement. This waste can occur because of poor layout, or also because the product is brought from one room to another so that it also causes other waste, which is waste of waiting. ${ }^{2}$

\section{Improving Design \\ Change of Casemix Team Structure}

Implementation of lean management can be successful if supported by strong leadership, staff empowerment, and commitment to make sustainable improvement. ${ }^{21}$ One thing that cause repetitive activity is too diverse team members who come from different divisions and work under different heads. Such structure may cause abundant and overlapping job description. Therefore, it is suggested that the Casemix Team and staffs should work under the Financial Division.

\section{Change of Layout}

Since poor layout contributes to waste, room layouts should be designed as following:

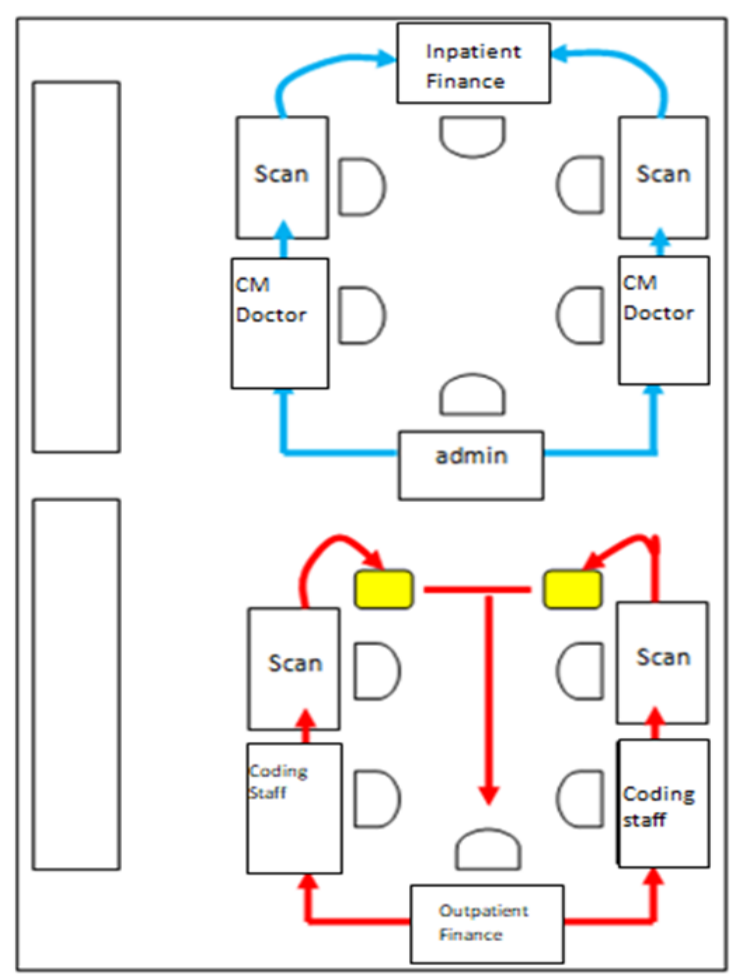

Picture 10. Recommendation for Casemix Team Layout

Red lines illustrate the flow of outpatient casemix files while blue lines illustrate inpatient casemix files. From 
Picture 10, everything is in a one-piece flow which minimizes the staff's movement in the same room.

\section{Casemix StaffingRegulation}

The repeated activity in the process is file checking by coding staffs and casemix doctors. Ideally, the financial staff and administrative staffs should handle this process. Coding staffs and casemix doctors have more understanding about medical matters so that they can complete files accurately.

Ideal layout and working condition, minimal waste, accurate calculation, ideal number of staffs consist of 1 outpatient financial staff, 1 inpatient financial staff, 2 coding staffs, 2 outpatient scanningstaffs, 2 inpatient scanner staffs, 2 casemix doctors. There are 14 members working in the team, but such ideal systems can decrease up 4 workers. The working hours are also designed gradually so as to save time. The outpatient financial staffshould starthis/her work at $7.00 \mathrm{AM}$ while thecoding staffs, scanningstaffs, and casemix doctors should also beginat 7.30 AM. Such schedule can give outpatient financial staff an opportunity to do a handover. Meanwhile, the inpatient financial staffwill startat 9.00 AM because she just can work after files have been finished from the cashier.

\section{Improving IT Program}

A good IT system can minimize waste of extra processing, waste of waiting, waste of defect, and waste of transportation.

\section{1) Designing an electronic medical record}

The purpose is to minimize waste of motion to submit complete files. Doctors can fill out the documents without borrowing the printed ones.

2) Improving input and splitting cost program

A good program can remove waste of extra processing. The staffs no longer have to manually calculateto submit aclaim.

\section{3) Improving Financial Program}

With a good financial program, the financial staffstaffsdonot re-input or match data because they can draw data from the same source.

Flowchart dan Future State Stream Mapping of Casemix Process

Flowchart of Outpatient Casemix after the application of Lean Management

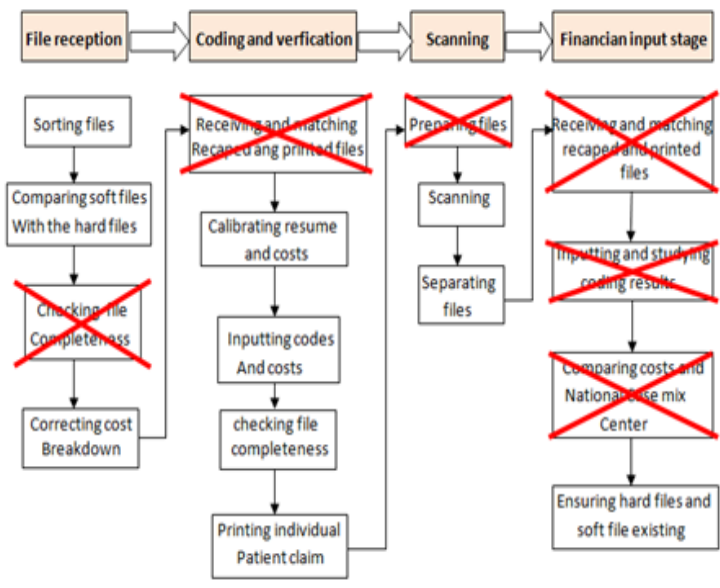

Picture 11. Flowchart of outpatient casemix process after the application of Lean Management

Based on Figure 11, the Lean Management can reduce the casemix process stages from 16 stages to 10 stages.

Future State Stream Mapping of Outpatient Casemix Process
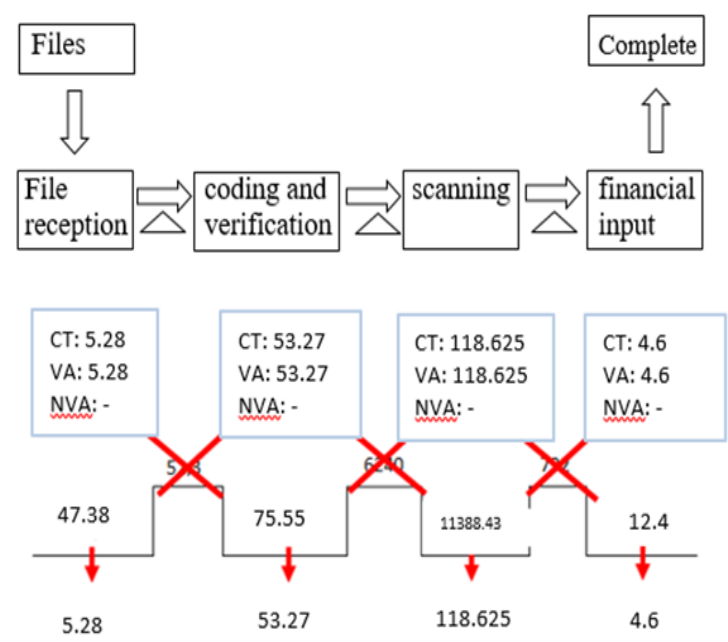

Picture 12. Future State Stream Mapping of Outpatient Casemix File Process

The overall cycle time can be reduced from 97.018 seconds to 181,78 seconds after the Lean Management is applied. 
Flowchart of Inpatient Casemix Process after the Application of Lean Management

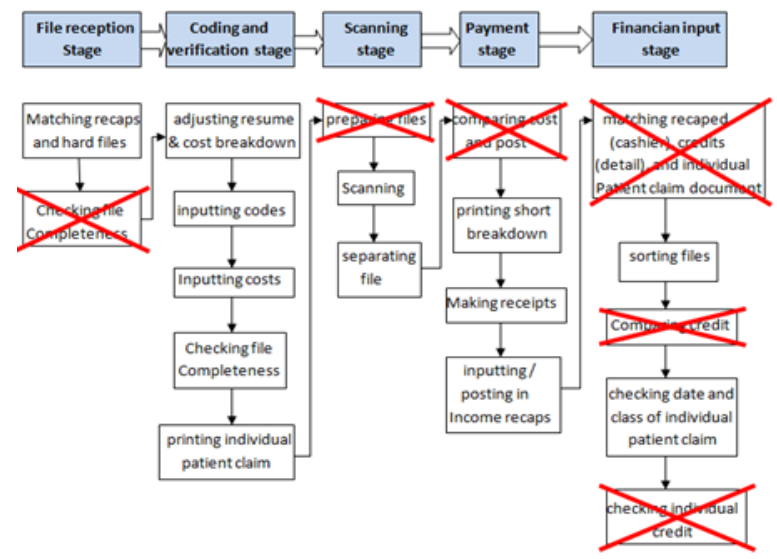

Picture 13. Flowchart of Inpatient Casemix Process After the Application of Lean Management

Based on Picture 13, Lean management can minimize up to 13 stages in the inpatient casemix process.

\section{Future State Stream Mapping of Casemix Process}

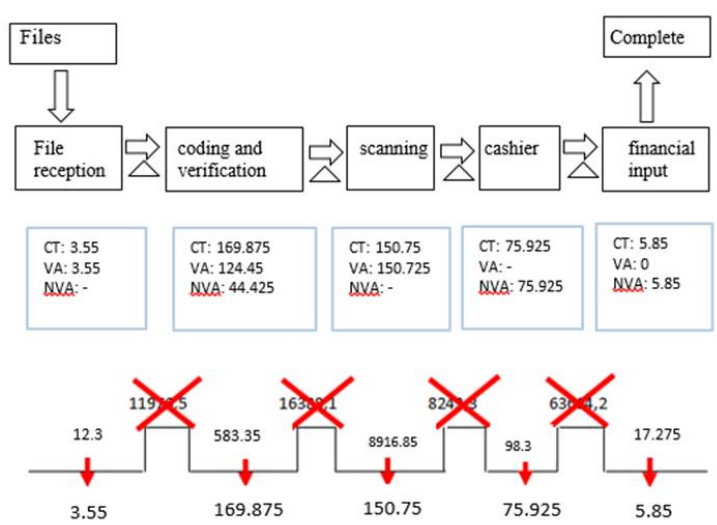

Picture 14. Future State Stream Mapping of Inpatient Casemix Process

The application of lean management performs no waste at all. Therefore, overall process cycle time is expected to decrease from 109.897 seconds to 405,95 seconds

\section{CONCLUSION}

The ongoing casemix process was not in the lean condition with the total waste of $52.4 \%$ in the outpatient casemix file process and $52.2 \%$ in the inpatient casemix file process. The wastes included waste of transportation, waste of motion, waste of waiting, waste of extra processing, and waste of defect. Overall, the waste of extra processing had the biggest composition.

There were most different types of waste between the service unit and administrative unit. In the service unit, the waste that is often found is waste waiting, while in this study where the research was conducted not in the service unit, the waste found was extra processing.

The IT support and good layout can reduce overall waste from 97.018 seconds to 181,76 seconds. It can also decrease overall cycle time of inpatient casemix process from 109.897 seconds to 405,95 seconds and the number of employees.

\section{REFERENCE}

1. Chalice R. Improving Healthcare using lean Toyota Production Method :46 steps for improvement. Meinholz M, editor. Tony, William; 2007

2. Graban M. Lean Hospital : Improving Quality, Patient Savety, and Employee Satisfaction. third edit. New York: CRC Press; 2009.

3. Delisle DR. Executing Lean Improvement. Mainholz M, O'Mara PD, editors. Milwaukee, Wisconsin: Lynelle Korte; 2015. 18-21 p.

4. Charron R, Harrington J, Voehl F, Wiggin H. The Lean Management System Handbook. CRC Press Taylor and Francis Group; 2015.

5. Young T, McClean S. A critical look at Lean Thinking in Healthcare. Br Med J. 2008;17:382-6

6. Marija K, Milos J, Djapan M, Zivanovic-Macuzic I. Lean thinking in healthcare : Review of implementation result. Int J Qual Res. 2016;10(1):219-30

7. Woolhandler S, Campbell T, Himmelstein DU. Costs of Health Care Administration in the United States and Canada. N Engl J Med [Internet]. 2003 Aug 21 [cited 2019 Jan 6];349(8):768-75. Available from: http://www.nejm.org/doi/abs/10.1056/NEJMsa02203 3

8. Berwick D, Hackbarth A. Eliminating Waste in US Healthcare. J Am Med Assoc. 2012;307(14):1513-6.

9. Ananta I. Penerapan Pola Pembayaran INA-CBGS BPJS Kesehatan Dalam Tinjauan Regulasi dan Implementasi. 2015.

10. BPJS. Peraturan Badan Penyelenggaran Jaminan Sosial nomor 3 tahun 2017 tentang Pengelolaan Administrasi Klaim Fasilitas Kesehatan dalam Penyelenggaraan Jaminan Kesehatan Nasional. 3 tahun 2017 Indonesia; 2017. 
11. Dumaris H. Analisis Perbedaan Tarif Rumah Sakit dan Tarif INA-CBGs Pelayanan Rawat Jalan di RSUD Budhi Asih Jakarta tahun 2015. J ARSI. 2016;20

12. Dickson EW, Singh S, Cheung DS, Wyatt CC, Nugent AS. Application of Lean Manufacturing Techniques in the Emergency Department. J Emerg Med [Internet]. 2009 Aug 1 [cited 2018 Nov 21];37(2):177-82. Available from: https://www.sciencedirect.com/science/article/pii/S07 36467908002163

13. Gaspersz V. The Executive Guide to Implementing Lean Six Sigma. Gramedia Pustaka Utama; 2007

Schonberger RJ. Reconstituting lean in healthcare: From waste elimination toward "queue-less" patientfocused care. Bus Horiz [Internet]. 2018 Jan 1 [cited 2018 Nov 21];61(1):13-22. Available from: https://www.sciencedirect.com/science/article/pii/S00 07681317301222

14. Fiore C. Lean Execution : The basic implementation guide for maximizing process performance. CRC Press; 2016

15. Hussain M, Malik M. Prioritizing lean management practices in public and private hospitals. J Health Organ Manag [Internet]. 2016 May 16 [cited 2019 Jan 6];30(3):457-74.Available from: http://www.emeraldinsight.com/doi/10.1108/JHOM08-2014-0135

16. Nancy. Pendekatan Lean Hospital untuk Perbaikan Berkelanjutan Proses Pelayanan Instalasi Farmasi RS BethesdaYogyakarta. Universitas Gajah Mada; 2017.

17. Chan H, Lo S, Lo W, Yu W, YF W, ST H, et al. Lean Techniques for The Improvement of Patients' Flow in Emergency Department. World Jounal Emerg Med. 2014;1(5):24-8

18. Apriyantini D. Analisis Hubungan Kelengkapan Pengisian Resume Medis Terhadap Kesesuaian Standar Tarif INA CBGs Instalasi Rawat Inap Teratai RSUP Fatmawati. ARSI. 2016;2(3):194

19. 20.Indar I, Naiem F. Faktor Yang Berhubungan Dengan Kelengkapan Rekam Medis di RSUD Pandjonga Dg Ngalle Takalar. AKK. 2013;2(2):10-8.

20. Niemeijer G, Trip A, De Jong L, Wendt K, Does R. Impact of 5 years of Six Sigma in a university medical centre. Q Manag Heal Care. 2012;21(4):2628. 